\title{
Inhibitory Effects of Brain Chondroitin Sulfate Proteoglycans on Neurite Outgrowth from PC12D Cells
}

\author{
Atsuhiko Oohira, ${ }^{1}$ Fumiko Matsui, ${ }^{1}$ and Ritsuko Katoh-Semba ${ }^{2}$ \\ Departments of 'Embryology and 'Perinatology, Institute for Developmental Research, Kasugai, Aichi 480-03, Japan
}

Soluble chondroitin sulfate proteoglycans (CSPGs), prepared from 10-d-old rat brain, were added to the culture medium of PC12D cells containing NGF to examine the effects on NGF-induced neurite outgrowth from the cells. PC12D cells, a flat-shaped variant of PC12 pheochromocytoma cells, are characteristic of prompt neurite formation in response not only to NGF, but also to CAMP-enhancing reagents such as forskolin. Brain CSPGs inhibited the neurite elongation irreversibly in a dose-dependent manner; complete inhibition was observed at a concentration of $50 \mathrm{nmol}$ uronic acid/ $\mathrm{ml}$. Closely similar dose-dependent inhibition was observed in the forskolin-induced neurite outgrowth from PC12D cells. NGF-induced neurite outgrowth from conventional PC12 cells was also inhibited completely by $50 \mathrm{nmol}$ uronic acid/ml CSPGs. Some brain CSPGs seemed to be inhibitory, but the cartilage-unique CSPG did not show any inhibitory effect. Chondroitin sulfate, a polysaccharide moiety of CSPGs, did not show any inhibitory effect even at a concentration of $\mathbf{2 5 0}$ $\mathrm{nmol}$ uronic acid/ml, while core proteins prepared from brain CSPGs by digestion with chondroitinase ABC exhibited inhibitory activity similar to that of intact CSPGs. This indicates that the site of the inhibitory activity exists in the core protein moiety of brain CSPGs. From these observations, it is conceivable that brain CSPGs are involved in the regulation of neuronal differentiation.

Chondroitin sulfate (CS) and heparan sulfate are the major sulfated glycosaminoglycans (GAGs) in the brain, and CS is predominant in the postnatal rat brain (Oohira et al., 1986). Biochemical studies have shown that there are several CS proteoglycans (CSPGs) with structurally different core proteins in the rat brain (Normand et al., 1988; Oohira et al., 1988; Gowda et al., 1989). Some of these CSPGs can be easily solubilized with a physiological salt solution, and others are associated with cellular membranes prepared from the brain (Herndon and Lander, 1990). Immunohistological studies demonstrated that CSPGs were localized extracellularly in the developing rat brain (Aquino et al., 1984). Although it has been suggested that neural CSPGs function as modulators of cell adhesion and of migration (for review, see Margolis and Mar-

\footnotetext{
Received July 17, 1990; revised Oct. 23, 1990; accepted Oct. 24, 1990.

This work was supported in part by Ichiro Kanahara Foundation Grant 89 K0005 and Daiko Foundation Grant 2172 to A.O. and by Grants-in-Aid 02220223 to A.O. and 63570376 to R.K.-S. from the Ministry of Education, Science, and Culture of Japan.

Correspondence should be addressed to Atsuhiko Oohira, Ph.D. at the above address.

Copyright (c) 1991 Society for Neuroscience $\quad 0270-6474 / 91 / 110822-06 \$ 3.00 / 0$
}

golis, 1989), their roles in the development of nervous systems are still poorly understood.

Neuritic growth from immature neurons is an important developmental step in the nervous systems. Several components of the extracellular matrix, including fibronectin, laminin, and some types of collagen, have been shown to promote neurite elongation of neuronal cells in vitro (Akers et al., 1981; Baron von Evercooren et al., 1982; Carbonetto et al., 1983; Davis et al., 1985; Lander et al., 1985). The effects of proteoglycans and their glycosaminoglycan chains on neuritic growth have also been investigated. Although a basement membrane-type heparan sulfate proteoglycan has been reported to have the neuritepromoting activity by itself (Hantez-Ambroise et al., 1987), it is generally considered that CSPGs do not affect neuritic growth significantly by themselves. However, proteoglycans prepared from the brain have never been used in this kind of experiment. Because brain CSPGs may be different in structure from those of other sources, it is of interest to examine the effect of brain proteoglycans on neuritic growth.

PC.12 pheochromocytoma cells begin to extend neurites in response to NGF (Greene and Tischler, 1976), so that the culture system of this cell line has often been used as an experimental model system to study the mechanisms operative in neuritic growth. PC12D cells, a flat-shaped variant of PC12 cells, are characteristic of the rapid response to NGF in neurite outgrowth (Katoh-Semba et al., 1987). In the present work, CSPGs, solubilized by PBS from $10-\mathrm{d}$-old rat brain, were added to the culture medium of PC12D cells in the presence of NGF to examine the effects on NGF-induced neurite outgrowth from the cells.

\section{Materials and Methods}

Preparation of CSPGs. CSPGs were solubilized with ice-cold PBS in the presence of protease inhibitors from the brains of 10-d-old SpragueDawley rats and were partially purified by stepwise elution from a DEAESephacel column and then by gel filtration on a Sepharose CL-4B column as described previously (Oohira et al., 1988). To prepare ${ }^{35} \mathrm{~S}$-sulfatelabeled CSPGs, rats were injected intracerebrally with $740 \mathrm{kBq} / \mathrm{rat}$ of carrier-free $\mathrm{Na}_{2}{ }^{-35} \mathrm{~S}-\mathrm{O}_{4}$ dissolved in $10 \mu \mathrm{l}$ PBS $24 \mathrm{hr}$ prior to extraction of brain CSPGs. CSPGs were eluted broadly from Sepharose CL-4B in the area, with $K_{\mathrm{av}}$ ranging from 0.1 to 0.6 (see Oohira et al., 1988, their Fig. 1). The whole peak was pooled and subjected to ultracentrifugation on a $\mathrm{CsCl}$ density gradient under dissociative conditions. CSPGs were recovered almost quantitatively in the bottom fraction, with a density of over $1.38 \mathrm{gm} / \mathrm{ml}$. The bottom fraction contained at least 5 different CSPG molecules, the core proteins of which have molecular weights of $250,220,150,130$, and $93 \mathrm{kDa}$ (Oohira et al., 1988). This fraction is hereinafter referred to as CSPG-mixture.

The brain CSPG with the $250-\mathrm{kDa}$ core protein (designated CSPG$250)$ was purified from the faster fraction $\left(K_{\mathrm{av}}, 0.15-0.32\right)$ of the broad peak eluted from Sepharose CL-4B as follows: This fraction was chro- 
matographed on a column $(1.4 \times 75 \mathrm{~cm})$ of Sepharose CL-6B at $4^{\circ} \mathrm{C}$ in $1 \mathrm{M}$ guanidine $\mathrm{HCl}$ and $50 \mathrm{~mm}$ Tris- $\mathrm{HCl}(\mathrm{pH}, 7.5)$ containing $2 \mathrm{~mm}$ EDTA, $1 \mathrm{~mm} N$-ethylmaleimide, and $0.2 \mathrm{~mm}$ phenylmethylsulfonyl fluoride at a flow rate of $7 \mathrm{ml} / \mathrm{hr}$. A fraction with $K_{\mathrm{av}}$ ranging from 0.12 to 0.25 was pooled and ultracentrifuged on a $\mathrm{CsCl}$ density gradient. The bottom fraction $(>1.45 \mathrm{gm} / \mathrm{ml})$ contained only CSPG-250.

A small CSPG mixture, which did not contain either CSPG-250 or the CSPG with the 220-kDa core protein (CSPG-220), was prepared from the most retarded fraction $\left(K_{\mathrm{av}}, 0.45-0.60\right)$ of the broad peak eluted from Sepharose CL-4B. This fraction contained 3 major CSPGs (CSPGs with core proteins of $M_{r} \mathrm{~s} 150,130$, and $93 \mathrm{kDa}$ ) and a minor CSPG with the 220-kDa core protein. To remove CSPG-220, the pooled fraction was chromatographed on the Sepharose CL-6B column as described above. A peak fraction with $K_{\mathrm{av}}$ ranging from 0.35 to 0.50 was pooled and subjected to ultracentrifugation on a $\mathrm{CsCl}$ density gradient as described above. The bottom fraction $(>1.38 \mathrm{gm} / \mathrm{ml})$ consisted mostly of CSPGs with 150-, 130-, and 93-kDa core proteins and no longer contained CSPG-220. This fraction is hereinafter referred to as small CSPGs.

The cartilage-unique CSPG, termed PG-H, was extracted from epiphyseal cartilages of neonatal rats and purified by a method described previously (Matsui et al., 1989).

All proteoglycan preparations were dialyzed against PBS containing $1 \mathrm{~mm}$ sodium azide at $4^{\circ} \mathrm{C}$ and stored at $-80^{\circ} \mathrm{C}$. The amount of hexuronate in the proteoglycan solutions was measured by the method of Bitter and Muir (1962), after precipitation of proteoglycans from aliquots of the dialysates with $70 \%$ ethanol containing $1 \%$ potassium acetate. Protein was determined using the Bio-Rad protein assay (BioRad, Richmond, CA).

Before addition of CSPGs to culture media, CSPGs were precipitated from PBS with ethanol-potassium acetate solution as described above. Precipitates were washed once with $70 \%$ ethanol containing $1 \%$ potassium acetate, then lyophilized under sterile conditions. Dried CSPGs were dissolved in the culture medium at a concentration of $1.0 \mu \mathrm{mol}$ uronic acid $/ \mathrm{ml}$ (the concentrations of core proteins were $164 \mu \mathrm{g} / \mathrm{ml}$ for CSPG-mixture, $87.8 \mu \mathrm{g} / \mathrm{ml}$ for CSPG-250, and $202 \mu \mathrm{g} / \mathrm{ml}$ for small CSPGs).

Preparation of chondroitin sulfate polysaccharide. Chondroitin sulfate (CS), the GAG moiety of CSPGs, was prepared from CSPG-mixture as follows: CSPG-mixture was treated sequentially with pronase, $0.2 \mathrm{~N}$ $\mathrm{NaOH}$, and $5 \%$ trichloroacetic acid to release CS from core proteins (Oohira et al., 1986). Crude CS $(5 \mu \mathrm{mol}$ uronic acid) was dissolved in $5 \mathrm{ml}$ of $2 \mathrm{M}$ urea, $15 \mathrm{~mm} \mathrm{NaCl}$, and $50 \mathrm{~mm}$ Tris- $\mathrm{HCl}(\mathrm{pH}, 7.5)$ at room temperature and applied to a column $(0.7 \times 11 \mathrm{~cm})$ of DEAE-Sephacel equilibrated with the same buffer. CS was eluted with a $15 \mathrm{~mm}$ to 0.7 $\mathbf{M ~ N a C l}$ gradient in the urea buffer (total, $100 \mathrm{ml}$ ) at a flow rate of 10 $\mathrm{ml} / \mathrm{hr}$. CS-rich fractions were pooled, and CS was precipitated by adding $3 \mathrm{vol}$ of $95 \%$ ethanol containing $1.3 \%$ potassium acetate at $0^{\circ} \mathrm{C}$. The CS preparation was further purified by gel filtration on a Sepharose CL$6 \mathrm{~B}$ column $(1.4 \times 75 \mathrm{~cm})$ in $1 \mathrm{M}$ guanidine $\mathrm{HCl}$ and $50 \mathrm{~mm}$ Tris- $\mathrm{HCl}$ $(\mathrm{pH}, 7.5)$ at a flow rate of $7 \mathrm{ml} / \mathrm{hr}$. CS, eluted from the column as a symmetrical peak with a $K_{\mathrm{av}}$ of 0.67 , was dialyzed against PBS containing $1 \mathrm{~mm}$ sodium azide at $4^{\circ} \mathrm{C}$.

In addition to the CS preparation from brain CSPGs, we used the following commercial preparations of GAGs in this work: chondroitin sulfate A (composed mainly of chondroitin 4-sulfate units) from whale cartilage, chondroitin sulfate C (composed mainly of chondroitin 6-sulfate units) from shark cartilage, dermatan sulfate from pig skin, heparan sulfate from bovine kidney, and hyaluronic acid from human umbilical cords (Seikagaku Kogyo, Tokyo).

Preparation of CSPG core proteins. CSPGs ( $1 \mu \mathrm{mol}$ uronic acid) were digested with $0.2 \mathrm{U}$ protease-free chondroitinase ABC (Seikagaku Kogyo, Tokyo) at $37^{\circ} \mathrm{C}$ for $1 \mathrm{hr}$ in $1 \mathrm{ml} 0.1 \mathrm{M}$ Tris- $\mathrm{HCl}(\mathrm{pH}, 7.5)$ containing $20 \mu \mathrm{g}$ bovine serum albumin, $30 \mathrm{~mm}$ sodium acetate, 2 mм EDTA, 1 mM $N$-ethylmaleimide, $0.2 \mathrm{~mm}$ phenylmethylsulfonyl fluoride, and 0.07 $\mathrm{mm}$ pepstatin. The enzyme reaction was stopped by adding $3 \mathrm{ml}$ of $95 \%$ ethanol containing $1.3 \%$ potassium acetate at $0^{\circ} \mathrm{C}$. After $1 \mathrm{hr}$ at $0^{\circ} \mathrm{C}$, the mixture was centrifuged to collect pelleted core proteins. The pellet was washed once with $70 \%$ ethanol and $1 \%$ potassium acetate at $4{ }^{\circ} \mathrm{C}$, then lyophilized under sterile conditions. Before use, core protein preparations were dissolved in culture media at a concentration equivalent to $1.0 \mu \mathrm{mol}$ uronic acid of intact CSPGs per $\mathrm{ml}$.

In every experiment, an aliquot $(5 \mu \mathrm{l})$ of the enzyme reaction mixture was subjected to SDS-PAGE under reducing conditions with dithiothreitol using a $3 \%$ stacking gel with a $6 \%$ separating gel to confirm the production of core proteins by digestion with chondroitinase $A B C$.

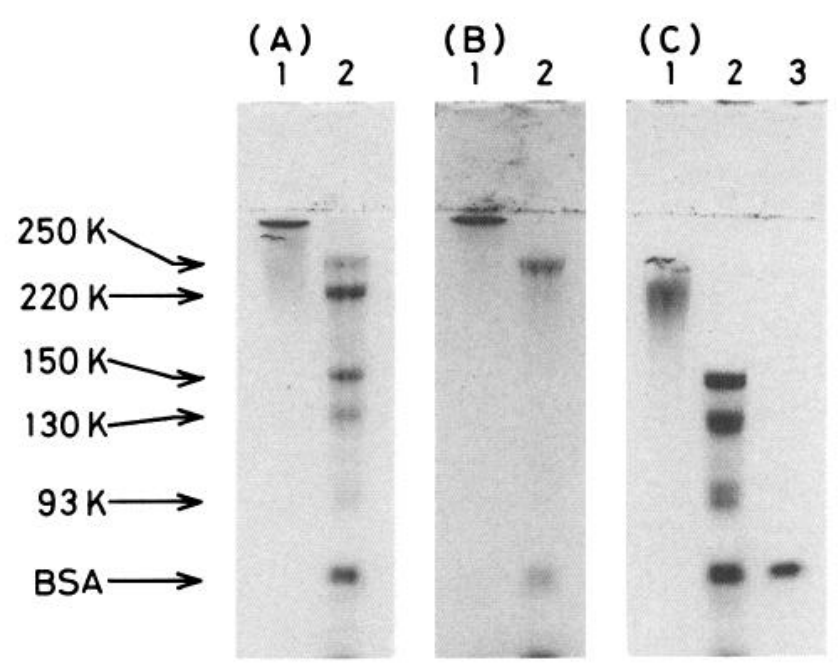

Figure 1. SDS-PAGE of CSPG-mixture $(A)$, CSPG-250 (B), and small CSPGs $(C)$. Lane 1, intact proteoglycan(s) before enzyme digestion; lane 2, core protein(s) prepared from the corresponding proteoglycan preparations by digestion with protease-free chondroitinase ABC. Enzyme reaction mixture without proteoglycan substrate was also analyzed $(C$, lane 3). Only bovine serum albumin (BSA), which had been added to the enzyme preparation as a stabilizer, was stained with Coomassie blue.

Cell culture. PC12D cells were grown on 100-mm tissue culture dishes in Dulbecco's modified Eagle's medium (DMEM; Gibco 430-2100) containing $44.4 \mathrm{~mm}$ sodium bicarbonate, supplemented with $5 \%$ fetal bovine serum (FBS) and $5 \mu \mathrm{g} / \mathrm{ml}$ insulin. Cells were harvested at mid-log phase in the same medium and reseeded on 96 -well plastic tissue culture plates, precoated with $0.1 \mathrm{mg} / \mathrm{ml}$ polylysine, at a density of $4.0 \times 10^{3}$ cells/well (or $1.3 \times 10^{4}$ cells $/ \mathrm{cm}^{2}$ ) unless otherwise indicated. After 24 $\mathrm{hr}$ of reseeding, the medium ( $100 \mu \mathrm{l} /$ well) was replaced with fresh medium containing 5 biological units/ml of $7 \mathrm{~S}$ NGF prepared by the method of Varon et al. (1972) and CSPGs at various concentrations up to $100 \mathrm{nmol}$ uronic acid/ml (or GAGs up to $250 \mathrm{nmol}$ uronic acid/ml). After $48 \mathrm{hr}$ in culture (total $72 \mathrm{hr}$ ), cells were fixed with $2 \%$ glutaraldehyde in PBS for $2 \mathrm{hr}$ at room temperature. Cells with processes equivalent in length to 2 or more diameters of the cell body were counted as neurite-bearing cells under a phase-contrast microscope.

Conventional $\mathrm{PC} 12$ cells were cultured under the same conditions as PC12 D cells, except for the substitution of $10 \%$ horse serum for insulin. The culture medium was changed every $2 \mathrm{~d}$. On day 9 of cultivation, cells were fixed as described above.

Viability of PC12D cells attached to the culture dishes was measured by the trypan blue exclusion test as follows: After cultivation, the medium was removed, and the cell layer was washed once with PBS at room temperature, prior to the addition of trypan blue ( $0.04 \%$ in PBS). After $10 \mathrm{~min}$ at room temperature, excess trypan blue was removed. The number of nonviable cells that absorbed trypan blue was counted under a light microscope.

\section{Results}

\section{Characterization of brain CSPGs}

Three proteoglycan preparations (CSPG-mixture, CSPG-250, and small CSPGs) were analyzed by SDS-PAGE before and after digestion with protease-free chondroitinase ABC (Fig. 1). When the intact CSPG-mixture was electrophoresed, most of it diffusely remained at the top portion of the separating gel. No other protein bands were detected in this preparation (Fig. $1 \mathrm{~A}$, lane 1). Digestion of CSPG-mixture with chondroitinase ABC produced several protein bands (Fig. $1 A$, lane 2 ). The molecular weights of the major core proteins have been estimated to be 250, 220, 150, 130, and $93 \mathrm{kDa}$ (Oohira et al., 1988). Intact CSPG-250 was recovered at the interphase between the stacking 

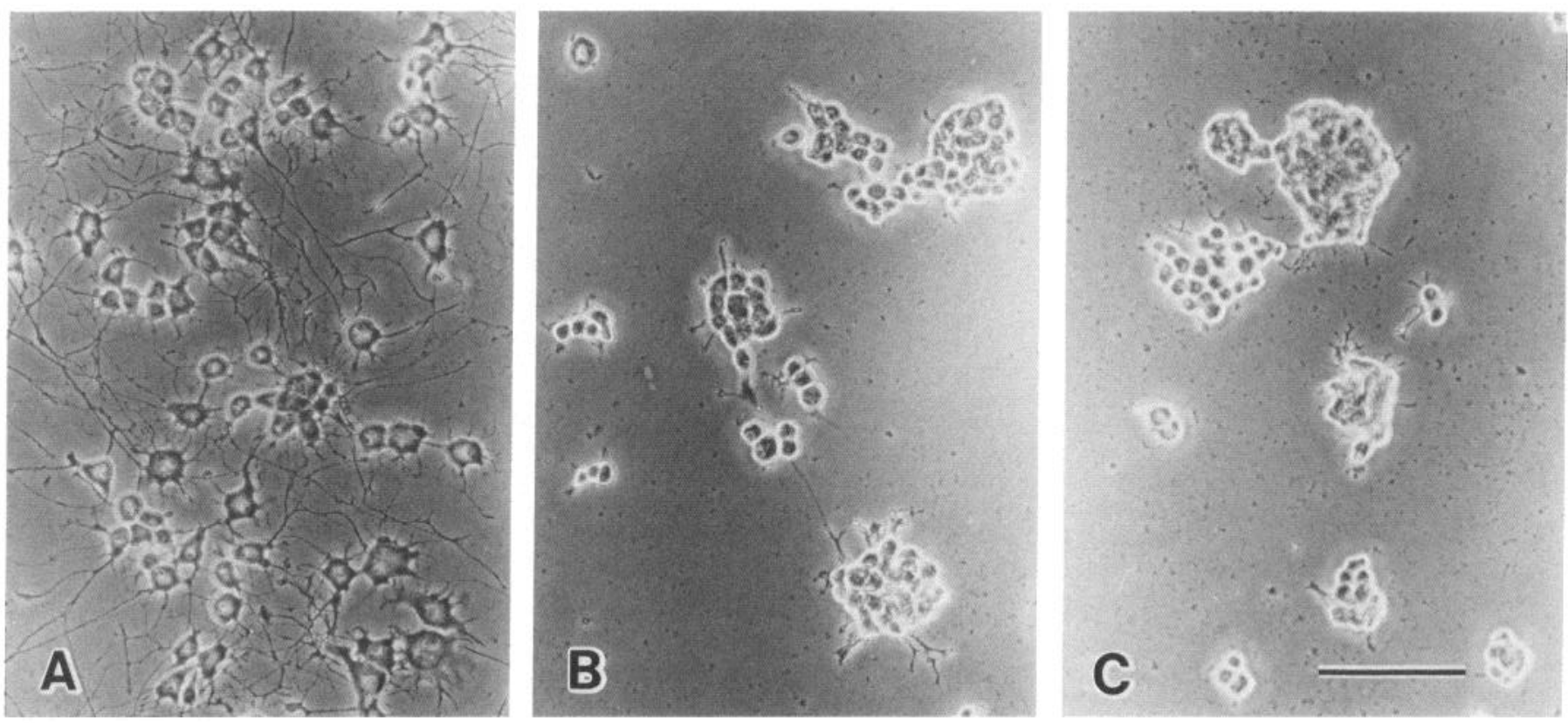

Figure 2. Photomicrographs of PC12D cells cultured for $48 \mathrm{hr}$ with NGF $(A)$, with NGF and $50 \mathrm{nmol}$ uronic acid/ml of CSPG-mixture $(B)$, and with NGF and core protein preparation from CSPG-mixture at concentration equivalent to $50 \mathrm{nmol}$ uronic acid/ml $(C)$. Scale bar, $100 \mu \mathrm{m}$.

and the separating gels, while CSPG-250 digested with chondroitinase $\mathrm{ABC}$ was observed as a single protein band with an $M_{r}$ of $250 \mathrm{kDa}$ (Fig. 1B). Digestion of small CSPGs with chondroitinase $A B C$ converted the very diffuse smear at 200-250 $\mathrm{kDa}$ (Fig. $1 C$, lane 1) into relatively sharp protein bands (Fig. $1 C$, lane 2). The major bands had molecular weights of 150 , 130 , and $93 \mathrm{kDa}$, and in this proteoglycan preparation, neither CSPG-250 nor CSPG-220 was detected.

\section{$N G F$-induced neurite outgrowth of PC12 and PC12D cells}

Conventional PC12 cells begin to extend their neurites after a lag period of a few days in response to NGF (Greene and Tischler, 1976), whereas PC12D cells immediately elongate their neurites (Katoh-Semba et al., 1987). Under culture conditions used here, the percentage of neurite-bearing PC12D cells reached a plateau after $48 \mathrm{hr}$, when about $70 \%$ of cells extended neurites (Fig. $2 A$; see also Fig. 4). In contrast, in the culture of conventional PC1 2 cells, it took more than 1 week, with a change of medium every $2 \mathrm{~d}$, for the percentage of neurite-bearing cells to reach a maximum level.

In the preliminary experiments, both conventional PC1 2 cells and PC12D cells were cultured in medium containing CSPGmixture at a concentration of 50 or $100 \mathrm{nmol}$ uronic acid $/ \mathrm{ml}$ in the presence of NGF. We found that either concentration of CSPG-mixture completely inhibited NGF-induced neurite outgrowth, not only from conventional PC12 cells, but also from PC12D cells (Fig. $2 B$ ). Therefore, to take advantage of the shortterm culture, we used mainly PC12D cells in the present work.

\section{Dose-dependent inhibition of neurite outgrowth}

To examine whether the inhibition by brain CSPGs of NGFinduced neurite outgrowth from PC12D cells occurred in a dosedependent manner, CSPG-mixture was added to the culture medium at various concentrations. No inhibition was observed at concentrations less than $1 \mathrm{nmol}$ uronic acid/ml (Fig. 3). The inhibitory effect became detectable around $1.5 \mathrm{nmol} / \mathrm{ml}$ and increased almost linearly with increasing concentration of CSPGmixture up to $15 \mathrm{nmol} / \mathrm{ml}$. Complete inhibition was observed at a concentration of $50 \mathrm{nmol}$ uronic acid $/ \mathrm{ml}$. At this concentration, PC12D cells were rounded and formed cell aggregates (Fig. $2 B$ ). Viability of cells cultured in the presence of both NGF and CSPG-mixture was $89.4 \pm 3.0 \%$ (mean \pm SD), which was virtually identical to that $(90.4 \pm 3.7 \%)$ of cells cultured in the presence of NGF alone.

To examine which CSPG(s) in CSPG-mixture was responsible for the observed inhibitory effects, either CSPG-250 or small CSPGs was added to the culture medium with NGF. Both CSPG250 and small CSPGs inhibited NGF-induced neurite outgrowth from PC12D cells in a dose-dependent manner similar to that of CSPG-mixture (Fig. 3). This finding indicates that some CSPG species, including CSPG-250, have the inhibitory activity.

PC12D cells extend neurites in response to cAMP-enhancing reagents, such as forskolin $(10 \mu \mathrm{M})$ in the culture medium, with a mechanism different from that operative in NGF-induced neurite outgrowth (Katoh-Semba et al., 1987). Therefore, it was of interest to examine whether or not brain CSPGs would inhibit forskolin-induced neurite outgrowth from PC12D cells. Brain CSPGs inhibited the neurite elongation induced by forskolin in a dose-dependent manner closely similar to that for inhibition of NGF-induced neurite outgrowth (data not shown, but see Table 1).

\section{Effects of proteoglycan core proteins}

A proteoglycan has 2 structurally different domains, a core protein moiety and a GAG moiety. The GAG moiety of brain CSPGs is a CS polysaccharide composed mainly of chondroitin 4-sulfate units (Oohira et al., 1988). To examine whether or not CS polysaccharide has an inhibitory effect on neurite outgrowth, we carried out 2 different series of experiments. First, the car- 


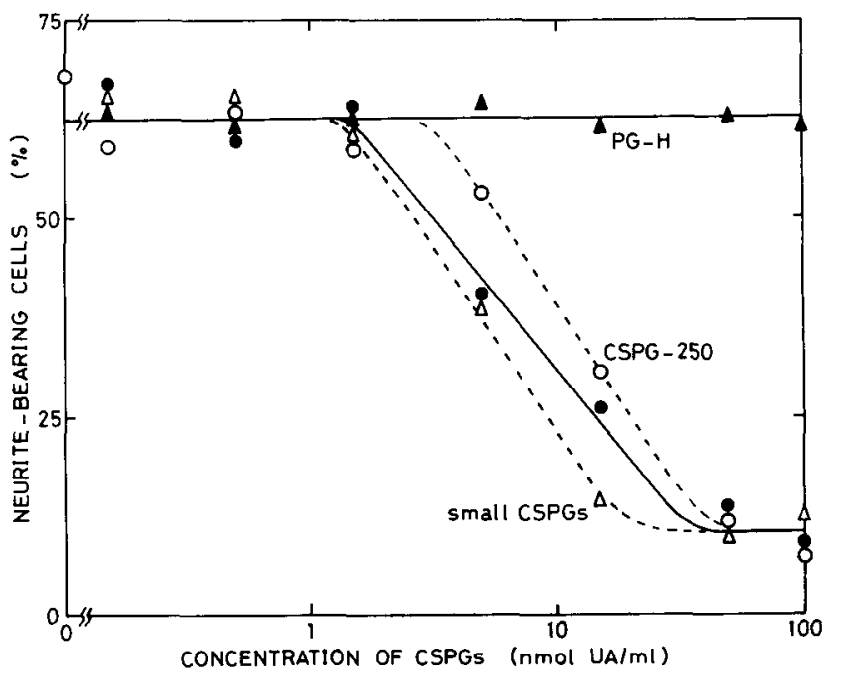

Figure 3. Dose-dependent effects of various CSPG preparations on NGF-induced neurite outgrowth of PC12D cells (Table 1, experiment 1). Solid circles, CSPG-mixture; open circles, CSPG-250; open triangles, small CSPGs; solid triangles, rat PG-H (the cartilage-unique proteoglycan). Each value represents the average of 3 determinations. $U A$, uronic acid.

tilage-unique CSPG, or PG-H, prepared from rat hyaline cartilage was added to the culture medium of PC12D cells, instead of brain CSPGs. Rat PG-H bears CS side chains abundant in chondroitin 4-sulfate units (Oohira and Nogami, 1980). The addition of rat PG-H did not cause inhibition of NGF-induced neurite outgrowth from PC12D cells even at a concentration of $100 \mathrm{nmol}$ uronic acid/ml (Fig. 3). Second, various GAGs, the polysaccharide moieties of proteoglycans, were added to the culture medium. CS polysaccharide prepared from CSPG-mixture had no effect on NGF-induced neurite outgrowth at a concentration of $50 \mathrm{nmol}$ uronic acid $/ \mathrm{ml}$. In addition, various commercial preparations of GAGs, such as chondroitin sulfate A, chondroitin sulfate $C$, dermatan sulfate, heparan sulfate, and hyaluronate, did not show any inhibitory effect even at a concentration of $250 \mathrm{nmol}$ uronic acid/ $/ \mathrm{ml}$. These observations imply that the site of inhibitory activity exists in a domain other than in the CS polysaccharide, namely, in the core protein moiety of CSPGs.

Core proteins prepared from CSPG-mixture, from CSPG250 , or from small CSPGs were added separately to the culture medium of PC12D cells at various concentrations. All these preparations inhibited NGF-induced neurite outgrowth from PC12D cells in a dose-dependent manner. The morphology of cells in the presence of core proteins was almost identical to that in the presence of the corresponding intact CSPGs (Fig. 2C for PC12D cells cultured with core proteins from CSPG-mixture at a concentration equivalent to $50 \mathrm{nmol}$ uronic acid $/ \mathrm{ml}$ ). Table 1 summarizes the dose at which the neurite outgrowth from PC12D cells is inhibited by $50 \%$ of the maximum level $\left(\mathrm{ID}_{50}\right)$ of intact CSPGs and their core proteins. The ID $_{50}$ of a core protein preparation was always higher (1.2-2.0-fold) than that of the corresponding proteoglycan preparation. This finding suggests that the primary inhibition site exists in the core protein moiety of brain CSPGs, but that an integral proteoglycan structure may be necessary for the full cxpression of inhibitory activity.
Table 1. ID 50 s of various CSPG preparations

\begin{tabular}{|c|c|c|c|c|}
\hline \multirow[b]{2}{*}{ Experiment } & \multirow[b]{2}{*}{ Molecular form } & \multicolumn{3}{|c|}{$\mathrm{ID}_{50}(\mathrm{nmol} \text { uronic } \mathrm{acid} / \mathrm{ml})^{a}$} \\
\hline & & $\begin{array}{l}\text { CSPG- } \\
\text { mixture }\end{array}$ & $\begin{array}{l}\text { CSPG- } \\
250 \\
\end{array}$ & $\begin{array}{l}\text { Small } \\
\text { CSPGs }\end{array}$ \\
\hline \multicolumn{5}{|c|}{ NGF-induced neurite outgrowth } \\
\hline Experiment 1 & Intact CSPGs & 6.6 & 11 & 5.0 \\
\hline \multirow[t]{2}{*}{ Experiment 2} & Intact CSPGs & $5.0(1.0)$ & - & $9.6(1.0)$ \\
\hline & Core proteins ${ }^{b}$ & $8.8(1.8)$ & - & $16.0(1.7)$ \\
\hline \multirow[t]{2}{*}{ Experiment 3} & Intact CSPGs & $3.3(1.0)$ & $4.3(1.0)$ & $2.5(1.0)$ \\
\hline & Core proteins & $4.0(1.2)$ & $7.4(1.7)$ & $5.1(2.0)$ \\
\hline \multicolumn{5}{|c|}{ Forskolin-induced neurite outgrowth } \\
\hline Experiment 1 & Intact CSPGs & 3.8 & 12 & 3.8 \\
\hline
\end{tabular}

\section{Effects of CSPGs on neurite-elongating cells}

In all the experiments described above, CSPGs were added to the culture medium with NGF at the same time. Therefore, we treated cells with CSPGs during elongation and when neurites were already fully elongated. As shown in Figure 4 , the percentage of neurite-bearing PC12D cells was $40-50 \%$ of total population after $15 \mathrm{hr}$ of cultivation in the presence of NGF. At this time, medium was replaced with fresh medium containing both NGF and CSPGs (50 nmol uronic acid/ml), and the culture was continued for a further $48 \mathrm{hr}$. The percentage of neurite-bearing cells did not increase in the presence of CSPG250 and tended to decrease slightly in the presence of CSPGmixture and small CSPGs (Fig. 4). This finding showed that brain CSPGs stop neurite elongation when they are added to the culture. When PC12D cells were cultured with NGF for 48 $\mathrm{hr}$, the proportion of neurite-bearing cells to the total population reached a plateau (Fig. 4). Brain CSPGs (50 nmol uronic acid/ $\mathrm{ml}$ ) were added to this culture, and the culture was continued for another $48 \mathrm{hr}$. The percentage of neurite-bearing cells decreased by about $20 \%$ in the case of CSPG-250 and by $30 \%$ in those of small CSPGs and CSPG-mixture (Fig. 4), suggesting that brain CSPGs retract some neurites from PC12D cells.

\section{Adsorption of CSPGs to culture}

We examined the reversibility of neurite outgrowth inhibition by brain CSPGs. PC12D cells pretreated with NGF and CSPGs (50 nmol uronic acid $/ \mathrm{ml}$ ) for $48 \mathrm{hr}$ were cultured for a further $24 \mathrm{hr}$ in fresh medium with NGF and without CSPGs. The percentage of neurite-bearing cells did not increase significantly. This indicates that the inhibition by brain CSPGs of neurite outgrowth from PC12D cells is irreversible, at least for the first $24 \mathrm{hr}$ after replacement of the medium. It is likely that brain CSPGs are adsorbed to the culture dishes and/or cells, and that the CSPGs attached to the culture cannot be washed out easily.

To estimate the amount of brain CSPGs adsorbed to the culture, ${ }^{35}$ S-labeled CSPG-mixture (specific radioactivity, 400 $\mathrm{dpm} / \mathrm{nmol}$ uronic acid) was added to the culture medium at a concentration of $50 \mathrm{nmol}$ uronic acid $/ \mathrm{ml}$ (or $20,000 \mathrm{dpm} / \mathrm{ml}$ ). As a control, ${ }^{35} \mathrm{~S}$-labeled CS polysaccharide with the same specific radioactivity was used. The amount of CS polysaccharide attached to the culture was $0.60 \mathrm{nmol}$ uronic acid $/ 60-\mathrm{mm}$ dish, 


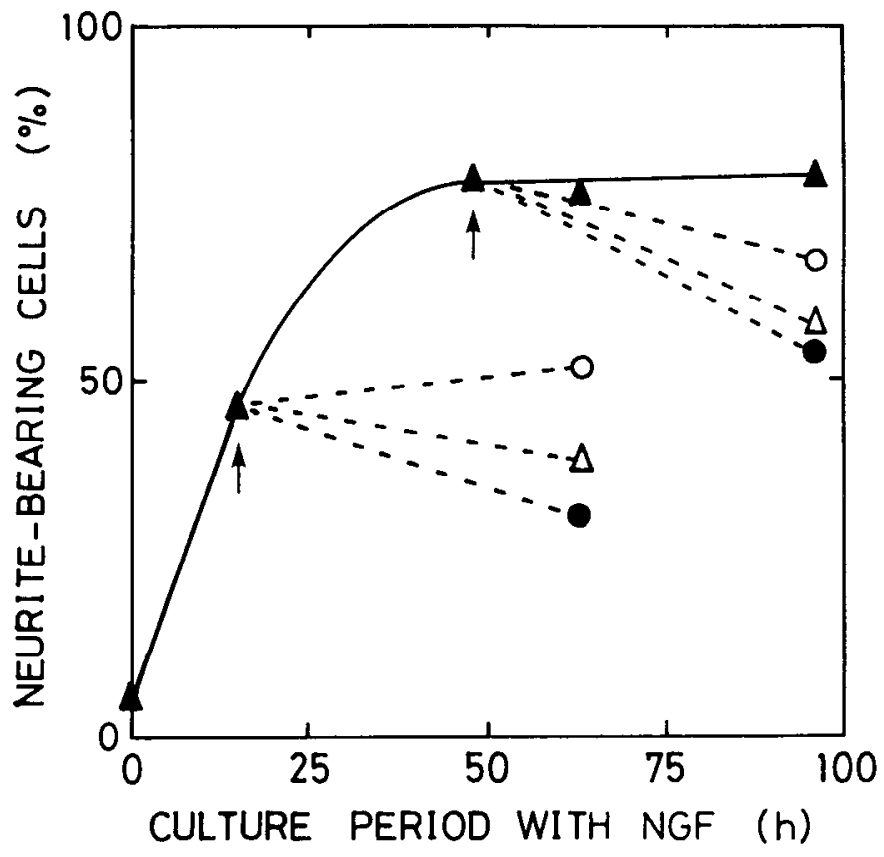

Figure 4. Addition of various CSPG preparations $(50 \mathrm{nmol}$ uronic acid/ml) to cultures of $\mathrm{PC} 12 \mathrm{D}$ cells during neurite elongation (at $15 \mathrm{hr}$ or at $48 \mathrm{hr}$ of cultivation with NGF). After addition of CSPGs, the culture was continued further for $48 \mathrm{hr}$, then the number of neuritebearing cells was counted. Solid triangles, without CSPGs; solid circles, CSPG-mixture; open circles, CSPG-250; open triangles, small CSPGs; arrows, time points when CSPGs were added to cultures.

and the amount did not vary irrespective of the presence of cells on the culture dish (Table 2). In contrast, over 3 times as many intact CSPGs as CS polysaccharides attached to the culture dish. PC12D cells adhering to the culture dish resulted in a further increase in the amount of attached CSPGs (Table 2). This increase could be attributed mainly to binding of CSPGs to PC12D cells.

\section{Discussion}

In the developing rat brain, CSPGs have been solubilized effectively with a physiological salt solution and are localized mainly in the intercellular space (Aquino et al., 1984). Therefore, addition of these soluble CSPGs to the culture medium of neural cells is a practical way to elucidate their roles in the behavior of neural cells. We have demonstrated that brain CSPGs solubilized with PBS inhibit both NGF-induced and forskolin-induced neurite outgrowth from PC12D cells when added to culture medium. The primary site of the inhibitory activity was also shown to exist in the core protein moiety of the soluble CSPGs of the brain.

Our present experiments address the role of CSPGs present in the soluble fraction from 10 -d-old rat brain. The insoluble or particulate fraction contains a distinct set of proteoglycans, and the composition of proteoglycans both in the soluble and in the particulate fraction changes with age (Herndon and Lander, 1990). Therefore, it is plausible that both soluble CSPGs of the brain at other developmental stages and membrane-associated proteoglycans play roles other than the inhibition of neurite outgrowth. In fact, a membrane-associated CSPG (Cat-301 antigen) expressed in the brain at a relatively late developmental stage has been implicated in the maturation of functional connections between neurons (Zaremba et al., 1989).
Table 2. Amounts of CS and CSPGs adsorbed to culture

Nmol uronic acid/dish ${ }^{a}$

CS ( $n=4$ from 2 separate experiments)

Dish without cells

$0.60 \pm 0.12(100)$

Dish with cells

$0.60 \pm 0.07(100)$

Difference

0

CSPG-mixture ( $n=5$ from 2 separate experiments)

Dish without cells

$2.0 \pm 0.2(330)$

Dish with cells

$2.9 \pm 0.3$

Difference

0.9

The cultures were carried out in 60 -mm culture dishes with $5 \mathrm{ml}$ of medium. ${ }^{35} \mathrm{~S}$ labeled CS or CSPG-mixture (specific radioactivity, $400 \mathrm{dpm} / \mathrm{nmol}$ uronic acid), instead of unlabeled CS or CSPGs, was added to the culture medium. After 48 hr of cultivation, the medium was removed, and the cell layer was washed with $1 \mathrm{ml}$ of PBS 3 times. Cells and materials attached to the dish were solubilized completely with $2 \%$ SDS and $50 \mathrm{~mm}$ Tris- $\mathrm{HCl}(\mathrm{pH}, 7.5)$ by the method described previously (Oohira et al., 1982). An aliquot of the SDS solution was mixed with Aquasol-2 (New England Nuclear, Boston, MA), and the "sS-radioactivity was measured. Control experiments were performed using $60-\mathrm{mm}$ dishes without cells.

a The values in the parentheses represent the percentage of the amount of CS adsorbed on a $60-\mathrm{mm}$ dish without cells.

Heparan sulfate proteoglycans from several sources promote neurite outgrowth either by themselves or through a functional complex with laminin (Lander et al., 1985; Matthew et al., 1985; Hantez-Ambroise et al., 1987; Dow et al., 1988). On the contrary, CS-rich substrata or CSPGs appear to inhibit neurite outgrowth. For example, Verna et al. (1989) cultured embryonic chick dorsal root ganglia on various GAG-bound collagen substrata and found that the binding of CS, not heparan sulfate, to collagen substrata decreased the ability of collagen to promote neurite elongation from the ganglia. Similar results were also reported by Akeson and Warren (1986) using PC12 cells cultured on GAG-containing artificial substrata. More recently, Muir et al. (1989) demonstrated that a proteoglycan-containing material produced by schwannoma cells could mask the neuritepromoting activity of laminin, and that the inhibitory activity of this material was eliminated by digestion with GAG lyases, including chondroitinase ABC. Furthermore, Snow et al. (1990) have shown that cartilage proteoglycan, which bears both $\mathrm{CS}$ and a small amount of keratan sulfate, inhibits the neurite extension from dorsal root ganglion neurons. Selective enzymatic removal of the $G A G$ moieties, leaving only the core protein moiety of the cartilage proteoglycan, resulted in a complete lack of inhibition. All these experiments indicate that the CS moicty of proteoglycans, rather than the core protein moiety, is responsible for the inhibition of neurite outgrowth. However, in our present work, the inhibitory activity of the brain CSPGs on neurite outgrowth was not eliminated by digestion of the $\mathrm{CS}$ polysaccharide moiety by protease-free chondroitinase $\mathrm{ABC}$ (Table 1). This is the first report to demonstrate that the core protein moiety of brain CSPGs can inhibit neurite elongation. Although the result shown in Table 2 suggests that the binding of brain CSPGs to PC12D cells with the core protein moiety is involved, the exact mechanism for the inhibition of neurite elongation from $\mathrm{PC} 12 \mathrm{D}$ cells by brain CSPGs remains unknown.

Although Snow et al. (1990) reported that cartilage proteoglycan inhibited neurite elongation from dorsal root ganglion neurons, we were unable to demonstrate this effect on neurite extension from PC12D cells (Fig. 3). This discrepancy may be due to a difference in cell type. Additionally, the difference in 
the proteoglycan concentration used may be another cause. Snow et al. (1990) cultured cells on nitrocellulose coated with the proteoglycan solution at a concentration of $1 \mathrm{mg} / \mathrm{ml}$, whereas we added it to the culture medium at various concentrations up to $100 \mathrm{nmol}$ uronic acid $/ \mathrm{ml}$ (about $50 \mu \mathrm{g}$ proteoglycan $/ \mathrm{ml}$ ), all of which were far lower than theirs.

Brain CSPGs have been shown to contain some glycoproteintype oligosaccharides, in addition to CS polysaccharide chains, covalently bound to the core protein polypeptides (Krusius et al., 1987; Gowda et al., 1989). Because the core proteins used in this work were prepared by digestion of brain CSPGs with protease-free chondroitinase $\mathrm{ABC}$, the glycoprotein-type oligosaccharides are considered to remain intact on the core protein polypeptides. In the present work, CSPG-250 inhibited the neurite outgrowth in a similar manner to that of small CSPGs (Fig. 3, Table 1). It is of interest to consider that CSPG-250 and other brain CSPGs bear a common glycoprotein-type oligosaccharide on their core protein polypeptides that inhibits neurite outgrowth.

Enormous efforts have been made to ascertain the neurotrophic factors that support the survival and/or differentiation of neuronal cells, but little attention has been paid to materials that can suppress the differentiation of neuronal cells. During brain development, a factor could suppress neuritogenesis of neuroblasts until a certain developmental stage. Similarly, in the mature brain, excess sprouting and elongation of neurites from neurons must be suppressed under physiological conditions. Recently, it has been shown that the brain contains some factors that inhibit neurite outgrowth. For example, Caroni and Schwab (1988) isolated 2 membrane protein fractions from rat central myelin that inhibited neurite growth. The $M, \mathrm{~s}$ of these proteins were estimated to be 250 and $35 \mathrm{kDa}$. Uchida and Tomonaga (1989) also found an inhibitory factor in aqueous extracts of normal human brains. Interestingly, this factor was not detectable in aqueous extracts of Alzheimer's disease brains. However, these factors seem to be different from soluble brain CSPGs, because the proteins isolated by Caroni and Schwab (1988) are membrane bound and have different physicochemical properties. The soluble factor reported by Uchida and Tomonaga (1989) inhibits both neuronal survival and neurite formation, while the brain CSPGs inhibit only neurite formation. No effect of the brain CSPGs on PC12D cell survival was observed.

\section{References}

Akers RM, Mosher DF, Lilien JE (1981) Promotion of retinal neurite outgrowth by substratum-bound fibronectin. Dev Biol 86:179-188.

Akeson R, Warren SL (1986) PC12 adhesion and neurite formation on selected substrates are inhibited by some glycosaminoglycans and a fibronectin-derived tetrapeptide. Exp Cell Res 162:347-362.

Aquino DA, Margolis RU, Margolis RK (1984) Immunocytochemical localization of a chondroitin sulfate proteoglycan in nervous tissue. I. Adult brain, retina, and peripheral nerve. J Cell Biol 99:1117-1129.

Baron von Evercooren A, Kleinman HK, Ohno S, Marangos P, Schwartz $P$, Dobois-Dalc ME (1982) Nerve growth factor, laminin and fibronectin promote neurite growth in human fetal sensory ganglia cultures. J Neurosci 2:179-194.

Bitter T, Muir HE (1962) Modified uronic acid carbazole reaction. Anal Biochem 4:330-334.

Carbonetto S, Gruver MM, Turner DC (1983) Nerve fiber growth in culture on fibronectin, collagen and glycosaminoglycan substrates. J Neurosci 3:2324-2335.

Caroni P, Schwab ME (1988) Two membrane protein fractions from rat central myelin with inhibitory properties for neurite growth and fibroblast spreading. J Cell Biol 106:1281-1288.
Davis GE, Manthorpe M, Engvall E, Varon S (1985) Isolation and characterization of rat schwannoma neurite-promoting factor: evidence that the factor contains laminin. J Neurosci 5:2662-2671.

Dow KE, Mirski SEL, Roder JC, Riopelle RJ (1988) Neuronal proteoglycans: biosynthesis and functional interaction with neurons in vitro. J Neurosci 8:3278-3289.

Gowda DC, Margolis RU, Margolis RK (1989) Presence of the HNK-1 epitope on poly $(N$-acetyllactosaminyl) oligosaccharides and identification of multiple core proteins in the chondroitin sulfate proteoglycans of brain. Biochemistry 28:4468-4474.

Greene LA, Tischler AS (1976) Establishment of a noradrenergic clonal line of rat adrenal pheochromocytoma cells which respond to nerve growth factor. Proc Natl Acad Sci USA 73:2424-2428.

Hantez-Ambroise D, Vigny DM, Koenig J (1987) Heparan sulfate proteoglycan and laminin mediate two different types of neurite outgrowth. J Neurosci 7:2293-2304.

Herndon ME, Lander AD (1990) A diverse set of developmentally regulated proteoglycans is expressed in the rat central nervous system. Neuron 4:949-961.

Katoh-Semba R, Kitajima S, Yamazaki Y, Sano M (1987) Neuritic growth from a new subline of PC12 pheochromocytoma cells: cyclic AMP mimics the action of nerve growth factor. J Neurosci Res 17: $36-44$.

Krusius T, Rcinhold VN, Margolis RK, Margolis RU (1987) Structural studies on sialylated and sulphated $o$-glycosidic mannose-linked oligosaccharides in the chondroitin sulphate proteoglycan of brain. Biochem J 245:229-234.

Lander AD, Fujii DK, Reichardt LF (1985) Purification of a factor that promotes neurite outgrowth: isolation of laminin and associated molecules. J Cell Biol 101:898-913.

Margolis RU, Margolis RK (1989) Nervous tissue proteoglycans. Dev Neurosci 11:276-288.

Matsui F, Oohira A, Shoji R, Nogami H (1989) Three distinct molecular species of proteoglycan synthesized by the rat limb bud at the prechondrogenic stage. Arch Biochem Biophys 275:192-201

Matthew WD, Greenspan RJ, Lander AD, Reichardt LF (1985) Immunopurification and characterization of a neuronal heparan sulfate proteoglycan. J Ncurosci 5:1842-1850.

Muir D, Engvall E, Varon S, Manthorpe M (1989) Schwannoma cellderived inhibitor of the neurite-promoting activity of laminin. J Cell Biol 109:2353-2362.

Normand G, Kuchler S, Meyer A, Vincendon G, Zanetta JP (1988) Isolation and immunohistochemical localization of a chondroitin sulfate proteoglycan from adult rat brain. J Neurochem 51:665-676.

Oohira A, Nogami H (1980) Age-related changes in physical and chemical properties of proteoglycans synthesized by costal and matrix-induced cartilages in the rat. J Biol Chem 255:1346-1350.

Oohira A, Wight TN, McPherson J, Bornstein P (1982) Biochemical and ultrastructural studies of proteoheparan sulfate synthesized by PYS-2, a basement membrane-producing cell line. J Cell Biol 92:357367.

Oohira A, Matsui F, Matsuda M, Shoji R (1986) Developmental change in the glycosaminoglycan composition of the rat brain. J Neurochem 47:588-593.

Oohira A, Matsui F, Matsuda M, Takida Y, Kuboki Y (1988) Occurrence of three distinct molecular species of chondroitin sulfate proteoglycan in the developing rat brain. J Biol Chem 263:10240 10246.

Snow DM, Lemmon V, Carrino DA, Caplan AI, Silver J (1990) Sulfated proteoglycans in astroglial barriers inhibit neurite outgrowth in vitro. Exp Neurol 109:111-130.

Uchida Y, Tomonaga M (1989) Neurotrophic action of Alzheimer's disease brain extract is due to the loss of inhibitory factors for survival and neurite formation of cerebral cortical neurons. Brain Res 481: 190-193.

Varon S, Nomura J, Percz-Polo JR, Shooter EM (1972) The isolation and assay of the nerve growth factor proteins. In: Methods and techniques of neurosciences (Fried R, ed), pp 203-229. New York: Marcel Dekker.

Verna JM, Fichard A, Saxod R (1989) Influence of glycosaminoglycans on neurite morphology and outgrowth patterns in vitro. Int $\mathbf{J}$ Dev Neurosci 7:389-399.

Zaremba S, Guimaraes A, Kalb RG, Hockfield S (1989) Characterization of an activity-dependent, neuronal surface proteoglycan identified with monoclonal antibody Cat-301. Neuron 2:1207-1219. 